\title{
THE JERUSALEM-HARVARD LECTURES
}

Sponsored by the Hebrew University of Jerusalem and Harvard University Press 


\section{$\infty$}

With thinking we may be beside ourselves in a sane sense.

Next to us the grandest laws are continually being executed.

Walden, Chapter V 


\section{A Pitch of Philosophy}

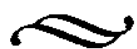

Autobiographical Exercises

\section{Stanley Cavell}

Harvard University Press

Cambridge, Massachusetts

London, England 
Copyright $(1994$ by the President and Fellows of Harvard College

All rights reserved

Printed in the United States of America

This book is printed on acid-free paper, and its binding materials have been chosen for strength and durability.

LIBRARY OF CONGRESS CATALOGING-IN-PUBLICATION DATA

Cavell, Stanley, 1926-

A pitch of philosophy : autobiographical exercises / Stanley

Cavell.

p. $\mathrm{cm}$. - (Jerusalem-Harvard lectures)

Includes bibliographical references and index.

ISBN 0-674-66980-0 (cloth)

ISBN 0-674-66981-9 (paper)

1. Philosophy. 2. Philosophy, American. 3. Cavell, Stanley,

1926-. I. Title. II. Series.

B945.C273P58 1994

$19 \mathrm{i}-\mathrm{d} \mathrm{c} 20$

[B] 